\title{
GAMBARAN BASIL TAHAN ASAM PADA PENDERITA TUBERKULOSIS PARU
}

\author{
Ice Ratnalela Siregar ${ }^{1}$, Mardan Ginting ${ }^{2}$, Halimah Fitriani Pane ${ }^{3}$ \\ Jurusan Laboratorium Medik, Poltekkes Kemenkes Medan ${ }^{123}$ \\ e-mail : icesiregar2103@gmail.com ${ }^{1}$,mardangtg@gmail.com ${ }^{2}$, halimah.fitriani@gmail.com ${ }^{3}$
}

\begin{abstract}
ABCTRACT
Tuberculosis is an acute and chronic infections disease that mainly attacks the lungs caused by acid-resistant bacteria (BTA) which are gram positive rods (Mycobacterium tuberculose). Tuberculosis can attack various organs, especially the lungs. This disease if not treated or treatment is incomplete can cause complications until death. The purpose of this study was to determine the description of Acid Resistant Basil in lung TB patients who have been diagnosed by Doctors at Puskesmas Pancurbatu Deli Serdang Regency. This research is descriptive with total population. The sample size in this study was 28 samples. Sputum speech from the study sample was examined by the Zhiel Neelsen staining method. The study was conducted at the Puskesmas Laboratory, Puskesmas Pancur Batu, Deli Serdang Regency. Data were analyzed descriptively. Based on the results of research conducted on Overview of acid-resistant bacilli (BTA) in Patients With Clinical Diagnosis OF Pulmonary Tuberculosis In Pancur Batu Public Health Center Deli Serdang District., apparently 20 samples (71\%) were negative and 8 samples (29\%) were positive. With the most positive results seen from the age of 17-48 years as many as 5 samples (62\%) and those seen from the male Gender as many as 5 samples (62\%). Therefore it is suggested further research is needed by conducting sputum culture in patients with suspected pulmonary tuberculosis but the results of sputum smear examination are negative.
\end{abstract}

Keywords : Tuberculosis, Acid Resistant Bacilli (BTA)

\begin{abstract}
ABSTRAK
Tuberkulosis adalah penyakit menular akut maupun kronis yang terutama menyerang paru yang disebabkan oleh bakteri tahan asam (BTA) yang bersifat batang gram positif (Mycobacterium tuberculose). Tuberkulosis dapat menyerang berbagai organ terutama paru-paru. Penyakit ini jika tidak diobati atau pengobatannya tidak tuntas dapat menimbulkan komplikasi hingga kematian. Tujuan penelitian ini adalah untuk mengetahui gambaran Basil Tahan Asam Pada Penderita TB Paru yang telah di Diagnosa Dokter di Puskesmas Pancur Batu Kabupaten Deli Serdang. Penelitian ini merupakan deskriptif dengan total populasi. Besar sampel pada penelitian ini adalah 28 sampel. SpeSimen sputum dari sampel penelitian diperiksa dengan metode Pewarnaan Zhiel Neelsen. Penelitian di lakukan di Laboratorium Puskesmas Puskesmas Pancur Batu Kabupaten Deli Serdang.data hasil penelitian dianalisis secara deskriptif. Berdasrkan hasil penelitian yang telah dilaksanakan tentang Gambaran Basil Tahan Asam (BTA) Pada Penderita Diagnosa Klinis Tuberkulosis Paru Di Puskesmas Pancur Batu Kabupaten Deli Serdang, ternyata 20 sampel (71\%) negatif dan 8 sampel (29\%) positif. Dengan hasil positif terbanyak dilihat dari umur 17-48 tahun sebanyak 5 sampel (62\%) dan yang dilihat dari Jenis Kelamin laki-laki sebanyak 5 sampel (62\%). Denga demikian disarankan Perlu dilakukan penelitian lanjut dengan melakukan kultur sputum pada penderita terduga tuberkulosis paru namun hasil pemeriksaan sputum BTA negatif.
\end{abstract}

Kata Kunci : Tuberkulosis, Bakteri Tahan Asam (BTA)

\section{PENDAHULUAN}

\section{Latar Belakang}

Program Nasional pengendalian TB di Indonesia dengan Visi TB tidak lagi menjadi masalah kesehatan masyarakat, dan dengan misi menjamin setiap penderita TB mempunyai akses terhadap diagnosis yang bermutu tinggi, pengobatan adekuat dan kesembuhan, menurunkan penularan, menurunkan kesakitan dan kematian TB serta mengakhiri ketidakadilan dan mengurangi dampak sosial ekonomi akibat penyakit TB. Ada lima elemen strategi DOTS yaitu Komitmen politis, Diagnosa Dengan Mikroskop, Pengawasan Jangka Pendek dan Pengawasan Langsung, Jaminan ketersediaan OAT yang bermutu serta Monitoring dan Evaluasi (Profil Dinkes Medan, 2019).

Tingginya prevalensi TB paru saat ini disebabkan oleh berbagai alasan seperti sosial 
ekonomi yang rendah, perlindungan kesehatan yangtidak mencukupi, kurangnya pengetahuan masyarakat tentang penyakit. Kuman TB jika tidak segera diobati akan terus berdiam di dalam tubuh,danadanya epidemi HIV terutama di negara berkembang (Puspitasari, 2018). Kuman TB akan menggerogoti paru -paru hingga dapat menyebar ke bagian tubuh lainnya melalui aliran darah. Kuman ini dapat menyerang tulang, merusak hati dan ginjal, jantung dan berbagai organ lainnya, menurunkan sistem kekebalan tubuh dan terjadi penurunan berat badan yang signifikan sehingga jika dibiarkan dapat menyebabkan kematian. (Chandra A, 2013)

Menurut Kementerian Kesehatan Tahun 2018 Indonesia berpeluang mencapai penurunan angka kesakitan dan kematian akibat TB menjadi setengahnya di tahun 2018, jika dibandingkan dengan data tahun 1990. Angka Prevalensi TB yang ada pada tahun 1990 sebesar 443 per 100.000 penduduk, Pada tahun 2015 ditargetkan menjadi 280 per 100.00 penduduk. Berdasarkan hasil survei prevalensi TB tahun 2013, Prevalensi TB paru smear positif per 100.000 penduduk umur 15 tahun keatas sebesar 257. Angka notifikasi kasus menggambarkan cakupan penemuan kasus TB paru Secara umum angka notifikasi kasus TB positif baru dan semua kasus dari tahun ke tahun di Indonesia mengalami peningkatan. Angka notifikasi kasus (Case notification rate/CNR) pada tahun 2015 untuk semua kasus sebesar 117 per 100.000 penduduk. (Kemenkes, 2018)

Pada tahun 2018 di Sumatera Utara diperoleh angka (Case notification rate /CNR) kasus TB Paru (+) yang kemudian diikuti Kabupaten Deli Serdang sebesar 2090 kasus. (Dinkes 2018)

Tuberkulosis adalah penyakit menular akut maupun kronis yang terutama menyerang paru yang disebabkan oleh bakteri tahan asam (BTA) yang bersifat batang gram positif (Mycobacterium tuberculose). Di Indonesia tuberkulosis masih merupakan masalah besar dan merupakan penyebab kematian nomor dua di dunia setelah India, Multidrug Resistance (MDR) $\mathrm{TB}$ merupakan penyakit $\mathrm{Tb}$ yang telah mengalami resistensi terhadap obat isoniazid (INH) dan rifampicin. Tuberkulosis dapat menyerang berbagai organ terutama paru-paru.
Penyakit ini jika tidak diobati atau pengobatannya tidak tuntas dapat menimbulkan komplikasi hingga kematian.

Tuberkulosis paru penyakit saluran pernafasan bagian bawah, basik mycobacterium tersebut masuk ke dalam jaringan paru melalui saluran pernafasan (droplet infection) sampai alveoli selanjutnya menyebar ke kelenjar getah bening. Pada saat ini terbentuklah primer kompleks (rankea) dinamakan Tuberkulosis Primer yag dalam perjalanan lebih lanjut sebgaian besar mengalami penyebmbuhan (Tirtana BT , 2011).

Mycobacterium tuberculosis masuk ke dalam tubuh kemudian menyebabkan inflamasi. Inflamasi merupakan mekanisme tubuh untuk mempertahankan diri dari benda asing yang masuk, misalnya invasi mikroorganisme, trauma, bahan kimia, faktor fisik dan alergi. Pendeteksian awal penderita TB dengan melakukan pemeriksaan sputum yang sering kita sebut dengan pemeriksaan mikroskopis BTA (Basil Tahan Asam). Kualitas pemeriksaan sediaan BTA menentukan kualitas Program Penanggulan Tuberkulosis (Arnadi dkk, 2015).

Pemeriksaan mikroskopis BTA dari sputum juga sangat berperan dalam mendiagnosis awal dan pemantauan pengobatan TB Paru. Epidemiologi sumber infeksi mycobacterium tuberculosis yang paling sering ialah manusia yang mengekspresikan basil tuberkel dalam jumlah banyak dari saluran nafas. Etiologi TB Paru berbentuk batang, kuman akan tumbuh optimal pada suhu sekitar $37^{\circ} \mathrm{C}$ dengan $\mathrm{PH}$ optimum 6,4-7. Sebagian besar kuman terdiri dari asam lemak yang menyebabkan kuman lebih tahan asam dan lebih kuat terhadap gangguan kimia dan fisik. Kuman tuberkulosis paru cepat mati dengan sinar matahari langsung, tetapi dapat bertahan hidup beberapa jam di tempat yang gelap dan lembap. Dalam jaringan tubuh kuman ini dapat dormant, tertidur lama selama beberapa tahun. (Buntuan, 2014)

Puskesmas pancur batu merupakan salah satu kecamatan yang berada di Kecamatan Pancur Batu. Puskesmas Pancur Batu terletak di J1. Jamin ginting KM 17,5 Desa Tengah Kecamatan Pancur Batu Kabupaten Deli Serdang dengan luas wilayah kerja puskesmas Pancur Batu 4037 Ha.Kecamatan Pancur Batu berada 
pada ketinggian $160 \mathrm{M}$ dari permukaan laut dengan batas-batas daerah sebelah utara berbatasan dengan Medan Tuntungan/Sunggal,Sebelah selatan berbatasan dengan Kecamatan Sibolangit,Sebelah timur berbatasan dengan Namorambe, Tetapi wilayah kerja puskesmas Pancur batu hanya terdiri dari 22 desa dan terdiri dari 96 dusun/lingkungan,selebihnya menjadi wilayah kerja puskesmas Sukaraya.

Puskesmas Pancur Batu kabupaten Deli Serdang,mempunyai pelayanan di dalam gedung dan di luar gedung.Pelayanan di dalam gedung antara lain poli umum, gigi, KIA/KG, ruang tindakan, apotik ,gedung obat, ruang imunisasi, ruang laboratorium, dan lain lain.Sedangkan pelayanan di luar gedung antara lain posyandu lansia, posyandu balita, penyuluhan kesehatan, pelacakan kasus, Surveillance. Beberapa pokok program Puskesmas yaitu promosi kesehatan, pencegahan penyakit menular (Pelacakan kasus TB, kusta, DBD, ISPA, Diare, dan penyakit menular seksual). pengobatan poli klinik umum dan gigi, kesehatan ibu dan anak, upaya peningkatan gizi serta kesehatan lingkungan (pemberantasan jentik nyamuk).(Profil Puskesmas Pancur Batu, 2019).

Penderita TB paru di puskesmas Pancur Batu tiap tahun terjadi peningkatan, Pada tahun 2018 terdapat 2092 penderita, Sedangkan tahun 2019 sebanyak 2443 penderita,Berdasarkan data diatas terjadi peningkatan signifikan.Data pasien batuk denganb suspect TB yang datang ke puskesmas pancur batu pada tahun 2019 di laporkan mencapai 80 org dan ditemukan BTA positif terhadap suspect sebesar $46,67 \%$ (Profil puskesmas pancur batu 2019).

Mengingat dampak merugikan dan berbahaya yang akan dialami oleh masyarakat akibat TB paru dan masih tingginya angka kejadian di Kabupaten Deli Serdang khususnya di puskesmas Pancur Batu maka sangat penting untuk mengetahui secara dini apakah terdapat kuman mycobacterium tuberculosis yang menyebabkan TB paru.

\section{Rumusan Masalah}

Berdasarkan latar belakang diatas, peneliti tertarik untuk melakukan penelitian mengenai Bagaimana Gambaran Basil Tahan
Asam Pada Penderita TB Paru yang telah di diagnosa dokter di Puskesmas Pancur Batu Kabupaten Deli Serdang.

\section{Tujuan Penelitian}

\section{Tujuan Umum}

Untuk mengetahui gambaran Basil Tahan Asam Pada Penderita TB Paru yang telah di Diagnosa Dokter di Puskesmas Pancur Batu Kabupaten Deli Serdang.

\section{Tujuan Khusus}

Untuk menentukan gambaran Basil Tahan Asam Pada Penderita TB Paru yang telah di Diagnosa Dokter di Puskesmas Pancur Batu Kabupaten Deli Serdang.

\section{Manfaat Penelitian}

Pertama, memberikan informasi kepada penderita Tuberkulosis Paru bahwa pemeriksaan Mikroskopis BTA dapat dijadikan sebagai salah satu pemeriksaan untuk meninjau keberhasilan pengobatan pada penderita TB Paru. Kedua, sebagai bahan masukan untuk Dinas Kesehatan khususnya Puskesmas yang menangani pelacakan kasus sehingga penderita TB dapat menurun.

\section{METODE PENELITIAN}

\section{Jenis dan Desain Penelitian}

Penelitian ini menggunakan metode survei deskriptif yaitu dengan melakukan Pemeriksaan Sputum pada Penderita TB Paru

\section{Lokasi dan Waktu Penelitian}

\section{Tempat Penelitian}

Penelitian di lakukan di Laboratorium Puskesmas Puskesmas Pancur Batu Kabupaten Deli Serdang.

\section{Waktu Penelitian}

Penelitian dilakukan sejak bulan Juli sampai September 2020 dimulai dari mengumpulkan daftar pustaka, pengumpulan data dan pembuatan laporan hasil penelitian. 


\section{Populasi dan Sampel Penelitian}

\section{Populasi Penelitian}

Populasi seluruh penderita TB Paru yang berkunjung ke Puskesmas Pancur Batu Kabupaten Deli Serdang.

\section{Sampel Penelitian}

Sampel penelitian adalah seluruh penderita TB Paru yang berkunjung ke Puskesmas Pancur Batu Kabupaten Deli Serdang (Total Populasi).

\section{Jenis dan Cara Pengumpulan Data}

\section{Jenis Pengumpulan Data}

Jenis data adalah data primer yaitu data yang langsung diperoleh dengan cara melakukan pemeriksaan Mikroskopis BTA.

\section{Metode Pemeriksaan}

Metode pemeriksaan yang digunakan ialah dengan cara langsung yaitu membuat preparat atau sediaan langsung (Direct Smear) menggunakan object glass dan menggunkaan pewarnaan Zhiel Neelsen.

\section{Prinsip Pewarnaan Zhiel Neelsen}

Mycobacterium tuberculosis mempunyai lapisan dinding lipid (Mycolic acid) yang tahan terhadap asam. Proses pemanasan mempermudah masuknya Carbol Fuchsin ke dalam dinding sel. Dinding sel tetap mengikat zat warna Carbol Fuchsin walaupun dekolorisasi dengan asam alkohol.

\section{Alat - alat}

Alat yang digunakan adalah kaca sediaan yang baru dan bersih (frosted end slide), bambu/lidi, botol berisi pasir + desinfektan, lampu spiritus/bunsen, wadah pembuangan lidi bekas, desinfektan (lisol 5\%, alkohol 70\%, hipoclorid $0,5 \%$ ).

\section{Bahan}

Bahan yang digunakan adalah dahak penderita TB Paru Yang Berkunjung $\mathrm{Ke}$ Puskesmas

Cara Pengambilan Bahan yaitu : Pertama, mbil dengan lidi sampel dahak pada bagian yang purulent. Kedua, sebarkan secara spiral kecil-kecil dahak pada permukaan kaca sediaan dengan ukuran $2 \times 5 \mathrm{~cm}$. ketiga, keringkan pada temperature kamar. Keempat, masukkan lidi bekas kedalam wadah yang berisi desinfektan. Kelima, pinset sediaan kaca dijepit dan fiksasi 2-3 kali melewati api Bunsen. Keenam. pastikan apusan menghadap keatas.

\section{Reagensia}

Desinfektan (lisol 5\%), alkohol 70\%, hipoclorid 0,5\%, larutan Carbol Fuchsin dan Larutan Methylen Blue 0,1 \%. (Ganda Soebrata, 2015)

\section{Prosedur Kerja Pewarnaan}

Pertama, atur sediaan di atas rak, jangan terlalu rapat, buat jarak. Kedua, tuangkan Carbol Fuchsin 1\% hingga menutupi seluruh permukaan sediaan. Ketiga, pemanasannya itu panaskan sediaan dengan api sampai keluar uap (jangan sampai mendidih) dinginkan selama 10 menit. Keempat, pencuciannya itu buang Carbol Fuchsin perlahan-lahan. Kelima, bilas dengan air mengalir. Keenam, dekolorisasi yaitu tuangkan asam alkohol 3\% sampai 3 menit, bila masih ada warna merah ualngi 1 kali lagi hingga tunggu 3 menit. Ketujuh, pewarnaan latar yaitu tuangkan $0,1 \%$ methylene blue hingga menutupi seluruh sediaan dan biarkan 1 menit, buang larutan MB satu persatu Pertama, bilas dengan air bersih Kedua, keringkan pada rak pengering (Ganda Soebrata, 2015)

Ada beberapa kategori pembacaan menurut skala IUATLD :

1. Negatif (-) : tidak ditemukan BTA minimal dalam 100 lapang pandang

2. Scanty : 1-9 BTA dalam 100 lapang pandang (tuliskan jumlah BTA yang ditemukan)

3. $1+\quad$ : 10-99 BTA dalam 100 lapang pandang

4. $2+\quad$ : 1-10 BTA setiap 1 lapang pandang (periksa minimal 50 lapang pandang) 
5. $3+\quad: \geq 10$ BTA dalam 1 lapang pandang (periksa minimal 20 lapang pandang). (Kemenkes RI,2018)

\section{Analisis Data}

Analisis data yang digunakan dalam penelitian ini dilakukan secara manual disajika dalam bentuk diagram batang atau diagram pie dan dibahas sesuai daftar pustaka yang ada.

\section{HASIL}

Dari hasil pemeriksaan yang dilakukan terhadap 28 sampel pada pemeriksaan Gambaran Basil Tahan Asam Pada Penderita Tb Paru di Puskesmas Pancur Batu Kabupaten Deli Serdang, maka diperoleh hasil sebagai berikut :

\section{Berdasarkan Umur}

Berdasarkan umur dibagi menjadi dua kategori yaitu umur 17-48 tahun dan 49-80 tahun pengkategorian ini didasarkan atas umur terendah 17 tahun dan umur tertinggi 80 tahun.

Gambar 1. Berdasarkan umur

\section{Berdasarkan Umur}

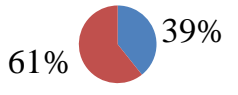

- Umur 17-48

- Umur 49-80

Berdasarkan Digram 3.1. pada 28 sampel yang dapat dilihat dari umur diperoleh umur 17 48 adalah 11 sampel (39\%), dan umur 49 - 80 adalah 17 sampel (61\%). Pada Penderita Tb Paru yang telah didiagnosa dokter di Puskesmas Pancur Batu Kabupaten Deli Serdang.

\section{Berdasarkan Jenis Kelamin}

Berdasarkan jenis kelamin dibagi menjadi dua kategori yaitu jenis kelamin laki-laki dan perempuan

Gambar 2. Berdasarkan jenis kelamin

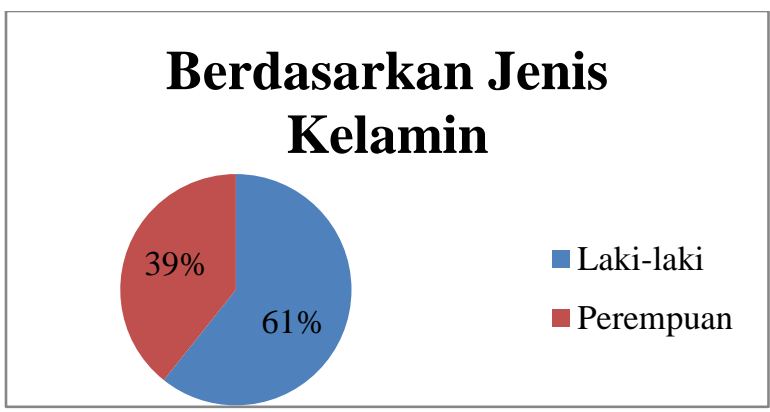

Berdasarkan Digram 4.2. pada 28 sampel yang didapat, dilihat dari jenis kelamin diperoleh yang berjenis kelamin laki-laki adalah 17 sampel (61\%), dan yang berjenis kelamin perempuan adalah 11 sampel (39\%). Pada Penderita Tb Paru yang telah di Diagnosa Dokter di Puskesmas Pancur Batu Kabupaten Deli Serdang.

\section{Berdasarkan Hasil yang Positif}

Berdasarkan hasil pemeriksaan BTA dibagi menjadi dua kategori yaitu positif dan negatif.

Gambar 3. Berdasarkan Hasil BTA

\section{Persentase Hasil BTA}

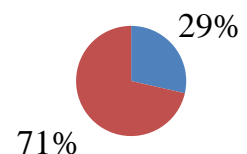

- positif

- Negatif

Berdasarkan Digram 4.3. pada 28 sampel yang didapat, dilihat dari hasil yang positif adalah 8 sampel (29\%), dan yang negatif sebanyak 20 sampel (71\%). Pada Penderita Tb Paru yang telah di Diagnosa Dokter di Puskesmas Pancur Batu Kabupaten Deli Serdang.

\section{Hasil Pemeriksaan BTA yang Positif Berdasarkan Umur}

Dari hasil pemeriksaan BTA yang positif berdasarkan umur dibagi menjadi dua kategori yaitu umur 17 - 48 tahun dan 49 - 80 tahun pengkategorian ini didasarkan atas umur terendah 17 tahun dan umur tertinggi 80 tahun.

Gambar 4. Hasil BTA positif berdasarkan umur 


\section{Hasil BTA Positif Berdasarkan Umur}

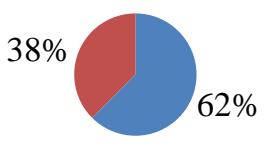

Umur 17-48

th

- Umur 49-80

th

Berdasarkan Digram 4.4. dari 28 sampel yang didapat, dilihat dari hasil yang positif berdasarkan umur 17 - 48 tahun sebanyak 5 sampel (62\%) dan umur 49 - 80 tahun 3 sampel ( $38 \%$ ). Pada Penderita Tb Paru yang telah di Diagnosa Dokter di Puskesmas Pancur Batu Kabupaten Deli Serdang.

\section{Hasil Pemeriksaan BTA yang Positif Berdasarkan Jenis Kelamin}

Dari hasil pemeriksaan BTA yang positif berdasarkan berdasarkan jenis kelamin dibagi menjadi dua kategori yaitu jenis kelamin laki-laki dan perempuan.

Gambar 5. Hasil BTA positif berdasarkan jenis kelamin

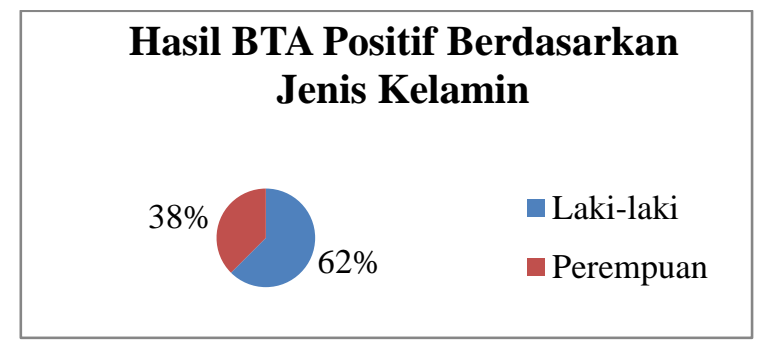

Berdasarkan Digram 4.5. dari 28 sampel yang didapat, dilihat dari hasil yang positif berdasarkan Jenis Kelamin laki-laki sebanyak 5 sampel (62\%) dan jenis kelamin perempuan 3 sampel (38\%). Pada Penderita Tb Paru yang telah di Diagnosa Dokter di Puskesmas Pancur Batu Kabupaten Deli Serdang.

\section{PEMBAHASAN}

Berdasarkan hasil penelitian yang telah dilakukan terhadap 28 sampel sputum Pada Penderita Tb Paru yang telah di Diagnosa Dokter di Puskesmas Pancur Batu Kabupaten Deli Serdang, ditemukan hasil pemeriksaan BTA yang positif sebanyak 8 sampel (29\%) dan yang negatif sebanyak 20 sampel (71\%). BTA yang paling banyak positif berdasarkan umur 17 - 48 adalah 5 sampel (62\%) dan yang berdasarkan jenis kelamin laki-laki 5 sampel (62\%).

BTA dari sputum juga sangat berperan dalam mendiagnosis awal dan pemantauan pengobatan TB Paru. Epidemiologi sumber infeksi mycobacterium tuberculosis yang paling sering ialah manusia yang mengekspresikan basil tuberkel dalam jumlah banyak dari saluran nafas (Buntuan, 2014).

\section{KESIMPULAN}

Dari hasil penelitian dapat disimpulkan pemeriksaan BTA positif pada pasien dengan dignosa klinis positif, yaitu : Pertama, berdasarkan jenis kelamin laki-laki $49-80$ tahun $(61 \%)$, dan perempuan 17 - 48 tahun. (39\%). Kedua, pemeriksaan BTA positif pada pasien dengan diagnosis klinis tuberkulosis paru berdasarkan umur, ditemukan pada kelompok umur 17 - 48 tahun $(62 \%)$ dan pada pada kelompok umur $49-80$ tahun $(38 \%)$. Ketiga, pemeriksaan BTA positif pada pasien dengan diagnosis klinis tuberkulosis paru paling banyak ditemukan pada laki - laki (61\%) dan perempuan (39\%)

\section{SARAN}

Pertama, memberikan penyuluhan dan edukasi pada masyarakat tentang pentingnya menjaga Kesehatan khususnya penyakit tuberculosis. Kedua, perlu kiranya dilakukan penelitian lanjutan dengan melakukan kultur sputum pada penderita tersangkatuberkulosis paru. Ketiga, perlu diperhatikan cara pengambilan sputum sehingga diperoleh sampel yang reprsentatif

\section{DAFTAR PUSTAKA}

Asril dkk, 2014 Tuberkulosis paru. Buku Ajar Ilmu Penyakit Dalam.Jilid II. Edisike-4. Jakarta: Pusat Penerbitan Departemen Ilmu Penyakit Dalam Fakultas Kedokteran Universitas Indonesia; 
Armadi, dkk, 2015. Tuberkulosis Paru pada Pasien Diabetes Mellitus. J Indon Med Assoc.2011;61(4).

Buntuan, 2014. Patofisiologi, Diagnosa dan Klasifikasi Tuberkulosis. Jurnal FKUI .

Bahar dkk, 2014. Faktor yang Berhubungan dengan Penyakit TB Paru padaLanjut usia di Pos Pembinaan Terpadu di Kelurahan Cempaka Putih Tahun 2012. Jurnal FKM UIN Jakarta

Chandra A, 2013. Hasil diagnostik Mycobacterium tuberculosis pada penderita batuk $\geq 2$ minggu dengan pewarnaan Ziehl-Neelsen di Puskesmas Ranomuut Jurnal e-Biomedik (eBm), Dinkes. 2018. Profil Kesehatan Sumatera Utara Tahun 2017

Ganda Soebrata, 2015. Pemeriksaan Laboratorium Klinik, Penerbit EGC Jakarta

Kemenkes RI, 2018. Profil Kesehatan Indonesia tahun 2019. Jakarta : Kemenkes RI

Novita, dkk, 2016. Hubungan Hasil Pemeriksaan Sputum Basil Tahan Asam dengan Gambaran Ulcus Lesi Tadiologi TB Paru di Rumah Sakit Islam Bandung. Jurnal Fakultas Kedokteran Universitas Islam Bandung

Depkes RI, 2014. Survey TB di Lima Puskesmas di Provinsi Jawa Timur. Diakses dari https://dinkes.jatimprov.go.id/ tanggal 25 September 2020

Puskesmas, 2020. Profil Puskesmas Pancur Batu Kabupaten Deli Serdang Tahun 2019

Puskesmas, 2020. Profil Puskesmas Pancur Batu Kabupaten Deli Serdang Tahun 2019

Puspitasari, 2018. Prevalensi diabetes Mellitus dan Hubungannya dengan Kualitas Hidup Lanjut Usia di Masyarakat. Universitas Medicina

Soedarto, 2018. Penatalaksanaan TB Paru Terpadu Sebagai Panduan Penatalaksanaan TB bagi Doketer Maupun Edukator. Jakarta : FKUI

Velma Buntuan, 2014. Diagnosa Gambaran Basil Tahan Asam (BTA) terhadap
Penderita TB Paru. Jurnal e-Biomedik (eBM) Bagian Mikrobiologi Universiotas Sam Ratulangi, Manado

Tirtana, 2011. Epidemiologi Penyakit Menular. Makassar.: PT. Raja Gravindo Persada 